Research paper

\title{
Reexamination of cell contents in Pennsylvanian spores and pollen grains using Raman spectroscopy
}

\author{
Abby L. Glauser ${ }^{\text {a,* }}$, Carla J. Harper ${ }^{\mathrm{a}}$, Thomas N. Taylor ${ }^{\mathrm{a}}$, Edith L. Taylor ${ }^{\mathrm{a}}$, \\ Craig P. Marshall ${ }^{\mathrm{b}}$, Alison Olcott Marshall ${ }^{\mathrm{b}}$ \\ a Department of Ecology and Evolutionary Biology, Natural History Museum, Biodiversity Institute, University of Kansas, Lawrence, KS 66045-7534, USA \\ b Department of Geology, University of Kansas, Lawrence, KS 66045-7534, USA
}

\section{A R T I C L E I N F O}

\section{Article history:}

Received 27 February 2014

Received in revised form 23 July 2014

Accepted 27 July 2014

Available online 11 August 2014

\section{Keywords:}

Intracellular inclusion

Nucleus

Permineralization

Coal ball

\begin{abstract}
A B S T R A C T
Permineralization offers exceptional structural preservation to the level of cellular components, many of which are found within fossilized plant specimens. In some cases, structures within plant cells, particularly those found within spores and pollen grains, have been interpreted as nuclei. Although these structures have been studied morphologically and ultrastructurally, little is known about their composition and origin. This study uses petrographic thin sections and ultraviolet (UV) Raman spectroscopy to reexamine cellular inclusions within three types of Pennsylvanian spores and pollen grains with the intent to interpret the molecular composition and therefore, the identity of these structures. Thin sections are examined using Raman spectroscopy, which indicates the presence of disordered carbonaceous material and calcite. There is no significant difference in the chemical composition between the intracellular inclusions and surrounding areas within each specimen. This study represents one of the first applications of Raman spectroscopy in which the internal cell contents of fossil plant taxa are analyzed. Results do not support the presence of nuclei, although further examination is recommended to elucidate the origin and identity of the intracellular inclusions.
\end{abstract}

(c) 2014 Elsevier B.V. All rights reserved.

\section{Introduction}

Historically, paleobotany has relied on several techniques to evaluate fossil plants, and to extract the greatest possible information from each specimen that can be applied to a variety of sub-disciplines (e.g., whole plant reconstructions, systematics, and paleoecology). The standard preparation technique for permineralized material was initially petrographic thin sections, which provided a wealth of information about cell types and tissue systems, especially those preserved within Carboniferous coal balls (Williamson, 1893; Hass and Rowe, 1999). Beginning in the 1950s, acetate peels were more frequently used to produce serial sections, which both accelerated the sectioning process and reduced the overall loss of material. Today, preformed cellulose acetate sheets are routinely used in the study of permineralized plant material from numerous stratigraphic levels (Galtier and Phillips, 1999). In recent years, however, it has become apparent that in some instances more detailed information is gained from thin sections, depending on the focus of the study (Taylor et al., 2011).

In some instances permineralization offers extraordinary preservation and allows for the interpretation of a variety of cell contents, some of which have been described as nuclei, chromatin granules, and mitotic chromosomes (Baxter, 1950; Schopf, 1968; Brack, 1970;

\footnotetext{
* Corresponding author. Tel.: + 17858644255.

E-mail address: a509g391@ku.edu (A.L. Glauser).
}

Brack-Hanes and Vaughn, 1978; Bonde et al., 2004; Bomfleur et al., 2014). These studies utilized transmitted light, scanning electron microscopy (SEM), and synchrotron radiation X-ray tomographic microscopy (SRXTM), with descriptions based on the relative size, shape, and consistency of cell contents within a population of cells of a particular type. Consistency is an important consideration, as sections of three-dimensional structures generally do not provide information for the contents of every cell present due to the focal plane in which the specimen is viewed. In some cases cell contents have been examined at the ultrastructural level; however, these studies have not provided additional information about the identity of cell contents (Taylor and Millay, 1977a).

Several techniques relatively new to the field of paleobotany have been used in recent years to enhance the study of fossil plants. These techniques have provided new information, and clarified concepts including cell types and organ reconstruction, cell wall composition, and the effects of taphonomic processes such as diagenetic transformation. Today scanning and transmission electron microscopy, spinning disc confocal microscopy, and X-ray microtomography are frequently used to gain further insights into the specimens investigated (e.g., Taylor et al., 2004; Schopf et al., 2006; Friis et al., 2007). The majority of these relatively new techniques emphasize the analysis of morphological features of a specimen.

Some analytical techniques recently applied to paleobiology offer the possibility of extracting more complex data from fossils. These 
approaches enable the observation of a broad range of chemical profiles from both the matrix and the fossil. Although such techniques have provided compositional information, they have not always offered data specific enough to define the systematic affinities of some fossils (e.g., Taylor et al., 2004). In some cases, however, the information obtained from these techniques gives insight as to the origins of a fossil or a questionable structure (Marshall et al., 2010, 2011; Nasdala et al., 2012). Raman spectroscopy in particular offers information about molecular structures, fossil biogenicity, and thermal maturity of specimens (Olcott Marshall et al., 2012). Originally developed for the use in the field of chemistry, Raman spectroscopy has become increasingly prominent in the field of paleobiology. Its applications range from the study of putative fossil microorganisms to the examination of extant organisms and biological molecules such as DNA and proteins, as well as the potential use for the investigation of possible biomolecules on Mars (Schopf et al., 2005; Tarcea et al., 2007; Marshall et al., 2010).

Several authors have stressed the importance of combining morphological data with chemical and molecular structural information to more confidently assess the biogenicity and origins of fossil material (Pflug and Jaeschke-Boyer, 1979; Schopf et al., 2005). The intent of this contribution is to analyze the contents of Carboniferous spores and pollen grains using ultraviolet (UV) Raman spectroscopy, and to determine the identity and molecular composition of these internal cell structures.

\section{Materials and methods}

\subsection{Locality and geological background}

The thermal maturity and geologic setting of specimens are useful when considering molecular composition. Because structural changes occur at the molecular level with exposure to heat and pressure, knowing the history of a specimen can help us interpret Raman data with more certainty. The specimens examined in this study all occur within calcium carbonate coal balls or concretions from several localities in North America.

Three representative structures were analyzed. Peltastrobus reedae is represented by a single specimen collected from the Petersburg or Alum Cave coal (Springfield Coal; Middle Pennsylvanian) from Booneville, Indiana (Baxter, 1950). This coal is part of the Petersburg Formation, and underlies the Alum Cave Limestone Member of the Dugger Formation (Guennel, 1952). Evidence suggests a fluvial channel depositional environment, where peat deposition occurred in fresh water adjacent to the channel (Eggert, 1982). Due to this non-marine depositional environment, these particular coals have a lower sulfur content than adjacent coals of the same seam underlying strata of marine origin (Treworgy and Jacobson, 1986). The Indiana No. 5 coals are directly overlain by black shales containing calcareous and pyritic concretions (Maples, 1986). Coal samples taken from the Petersburg Formation were found to have vitrinite reflectance values ranging from 0.388 to 0.655\% (Willard et al., 1995). These values indicate diagenetic alteration on the order of immature to mature thermal maturity for hydrocarbon generation.

Flemingites schopfii is represented by a single cone collected from the Copland Coal Member (Middle Pennsylvanian) from Lewis Creek, Kentucky (Brack, 1970). This coal is part of the Breathitt Formation, thought to be composed of deposits from a coastal zone or alluvial plain (Brack, 1970; Aitken and Flint, 1995).

Two representative specimens of Lasiostrobus polysacci originate from the Calhoun Coal Member (Upper Pennsylvanian) of the Berryville, Illinois locality (Taylor, 1970). This coal comes from the Mattoon Formation and underlies the Bonpas Limestone (Willard et al., 2007). The Calhoun Coal Member is of non-marine delta or channel origin (Wanless et al., 1969), and samples have been found to have vitrinite maceral contents of approximately 82-83\% (Harvey and Dillon, 1985).

\subsection{Fossil material}

All specimens were initially characterized using acetate peels. Specimens were prepared as paleontological thin sections without cover slips so that a greater degree of three dimensionality could be evaluated and spectroscopic analyses could be completed. Fragments of the specimens preserved in coal balls were smoothed using 600 grit silicon carbide and cleaned with ethyl alcohol. Specimens were mounted to standard microscope slides using Hillquist 2-part epoxy, then cut and ground using a Buehler thin section machine. Specimens were then ground to a desired thickness of approximately 35-50 $\mu \mathrm{m}$; in some instances digital images were taken and the specimen subsequently ground thinner. All specimens and slides are included in the Paleobotanical Collections, Natural History Museum and Biodiversity Institute, University of Kansas (Lawrence, KS). Thin sections include CB 15003 P1 TS1, CB 15003 P3 TS1, CB 2124 C2-1 TOP TS1, CB 2124 C2-1 TOP TS2, CB 2198 E2 SIDE TS1, and CB 902 E1B SIDE TS1. These slides were made from specimens CB 15003 P1, CB 15003 P3, CB 2124 C2-1 Top, CB 2198 E2 Side, and CB 902 E1B side.

Images were produced using a Leica DC500 CCD attached to a Leica DM5000B compound light microscope. Focal stacking of these images in Adobe Photoshop and Helicon Focus was used to further enhance detail and three-dimensional features.

Cell contents were examined from three taxa from the Carboniferous of North America. Although there are many examples of cell contents preserved in permineralized plants, those found in spores and pollen grains perhaps provide the best opportunity to examine the chemical components due to their abundance, uniformity, and ease of identification. These include the spores of Peltastrobus reedae, a sphenophyte, spores of the lycopsid Flemingites schopfii, and the pollen grains of Lasiostrobus polysacci, a cone of gymnospermous affinity. In section view, not every spore or pollen grain contains an intracellular inclusion, because in some grains these structures were lost due to the process of sectioning or are not visible due to the plane of section. All of the materials come from the original specimens upon which the taxa are based. Structural dimensions are based on measurements of 100 spores each from $P$. reedae and $F$. schopfii, each represented by a single cone, and 40 pollen grains from $L$. polysacci, represented in this study by two specimens.

\subsubsection{Peltastrobus reedae}

Peltastrobus reedae is a sphenophyte cone consisting of whorls of peltate sporangiophores (Baxter, 1950). Within the sporangia are ellipsoid, monolete spores that are $26-42 \mu \mathrm{m}$ in length and $16-23 \mu \mathrm{m}$ in width. The spore wall thickness is $0.3-1.2 \mu \mathrm{m}$ with an average thickness of $0.66 \mu \mathrm{m}$. In cross section, rounded structures protrude from the spore wall, and in some cases may project from the anterior and posterior poles. In the dispersed state the spores are most similar to the spore type Columnisporites ovalis (Courvoisier and Phillips, 1975).

Some spores contain well-defined central inclusions that range from spherical to ovoid in form, although several appear more irregular or partially fragmented (Plate I,10-12). They are nearly always more opaque than both the spore lumen and the spore wall. The inclusions frequently appear grainy, and some appear to contain more defined filamentous structures; however, this may be an artifact of the focal plane. Inclusion size ranges from 1.7 to $6.1 \mu \mathrm{m}$ in diameter with an average of $4.0 \mu \mathrm{m}$. These structures account for $1-10 \%$ of the area of the spore lumen, and on average occupy $3 \%$ of the lumen space. They occur one per spore and are abundant throughout the sporangia of $P$. reedae.

\subsubsection{Flemingites schopfii}

Flemingites schopfii (formerly Lepidostrobus schopfii) is a bisporangiate lycopsid cone (Brack, 1970). This study considers only microspores that contain inclusions. Immature spores occur in tetrahedral tetrads; in some sporangia individual spores are separated from the tetrad. Of the spores studied, 55 were found in tetrads and 45 were solitary. They are 

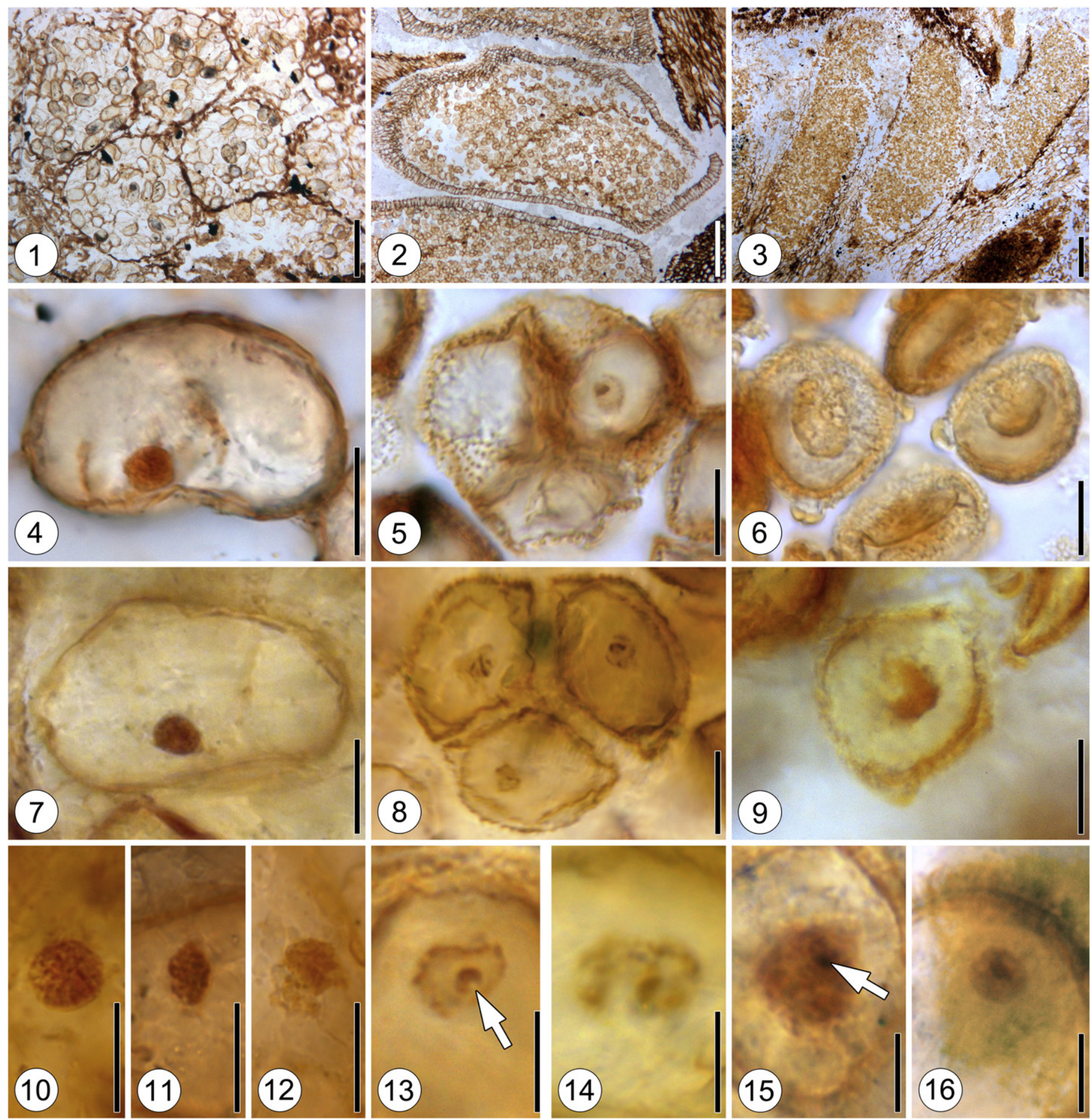

\section{Plate I.}

Fig. 1:

Fig. 2:

Fig. 3:

Fig. 4:

Fig. 5:

Fig. 6:

Fig. 7:

Fig. 8:

Fig. 9:

Fig. 10-12:

Fig. 13:

Fig. 14:

Fig. 15-16:

Section of Peltastrobus reedae cone showing sporangia containing microspores. CB 15003 P1-1, bar $=100 \mu \mathrm{m}$.

Section of Flemingites schopfii cone showing tightly packed spores within sporangia. 2124 C2-1 top 1, bar $=200 \mu \mathrm{m}$. Section through pollen sacs of Lasiostrobus polysacci containing tightly packed microspores. $2198 \mathrm{E} 1$ side, bar $=300 \mu \mathrm{m}$. Peel of $P$. reedae spore containing an intracellular inclusion. CB 15003 P2-2, bar $=10 \mu \mathrm{m}$

Peel of $F$. schopfii spores in a tetrad with one intracellular inclusion. 2124 C2-1 TOP 1, bar $=10 \mu \mathrm{m}$.

Peel of two $L$. polysacci pollen grains each containing a central inclusion. $2198 \mathrm{E} 1$ side, bar $=10 \mu \mathrm{m}$

Thin section of $P$. reedae spore containing a central inclusion. CB 15003 P3 TS1, bar $=10 \mu \mathrm{m}$.

Thin section of three F. schopfii spores in a tetrad, each with a central inclusion. CB 2124 top TS1, bar $=10 \mu \mathrm{m}$.

Thin section of two $L$. polysacci pollen grains with central inclusions. CB 902 E1B side TS1, bar $=10 \mu \mathrm{m}$

Range in morphology of the intracellular inclusions of P. reedae. CB 15003 P3 TS1, bars = $10 \mu \mathrm{m}$. Fig. 10 Spherical, to (11) ovoid, to (12) fragmented inclusions. Angular intracellular form within F. schopfii containing a smaller spheroidal structure indicated by arrow. CB 2124 C2-1 top TS1, TS2, bar $=5 \mu \mathrm{m}$. Irregular intracellular form within F. schopfii. CB 2124 C2-1 top TS1, TS2, bar $=5 \mu \mathrm{m}$.

Inclusions of $L$. polysacci indicating variation in size and morphology. (15) Larger inclusion with arrow indicating opaque internal structure, and (16) smaller inclusion. CB $902 \mathrm{E} 1 \mathrm{~B}$ side TS1, bars $=5 \mu \mathrm{m}$. 
$20-30 \mu \mathrm{m}$ in diameter, and the spore wall is $0.3-0.8 \mu \mathrm{m}$ thick with an average of $0.6 \mu \mathrm{m}$. The spores are trilete and when found as sporae dispersae are most similar to the miospore genus Microspinosporites (Bek, 2013).

Only single intracellular inclusions are found per spore and are commonly asymmetrical, although some are roughly spheroidal (Plate I, 8, 11). These structures are more opaque than the spore lumen, and often have a darker outline with a more transparent interior. In some specimens there is a smaller opaque spheroidal structure within the inclusion (Plate I, 13-14). Inclusions are 9.2-21.3 $\mu \mathrm{m}$ in diameter, with an average of $15.5 \mu \mathrm{m}$. These structures occupy approximately $2-8 \%$ of the area of the spore lumen, with an average of $4 \%$ of lumen space occupied.

\subsubsection{Lasiostrobus polysacci}

Lasiostrobus polysacci is a gymnospermous cone of unknown biological affinity characterized by helically arranged microsporophylls (Taylor, 1970). Pollen grains are ovoid, inaperturate, or rarely trilete, $20-30 \mu \mathrm{m}$ in diameter, and characterized by $3-8$ subequatorial sacci on their surface (Taylor, 1970; Taylor and Millay, 1977b). Between the sacci, the pollen grain wall consists of a uniformly thick ( $5 \mu \mathrm{m})$ inner layer that gives rise to columellae, which extend vertically and are fused to a uniformly thick ( $1 \mu \mathrm{m})$ tectum (Taylor, 1970). The thickness of the spore wall is $0.8-1.7 \mu \mathrm{m}$, averaging $1.3 \mu \mathrm{m}$. Although not assigned to any sporae dispersae genus, Lasiostrobus pollen has been compared morphologically and ultrastructurally to some extant conifer grains (Taylor and Millay, 1977b).

The individual inclusions found in $L$. polysacci are more difficult to discern than those of $P$. reedae or $F$. schopfii, because they are densely packed and few are completely contained in a single plane of section (Plate I, 3), which limited our ability to measure more than 40 pollen grains. Each pollen grain contains a spherical to ovoid, opaque body that ranges from 3.5 to $8.5 \mu \mathrm{m}$ in diameter with an average of $6.8 \mu \mathrm{m}$. These inclusions are generally more opaque than the cell lumen and spore wall, but in some cases appear more translucent than the spore wall (Plate I, 9). In some instances a smaller, more opaque body is evident within the inclusions (Plate I, 15). Central inclusions occupy approximately $11-48 \%$ of the lumen space, with an average of $25 \%$ of the lumen occupied.

\subsection{Raman spectroscopy}

The specimens selected for this study contain central inclusions that have been formerly interpreted as containing some form of nuclear material. Since these initial descriptions were based on transmitted light microscopy, and in some instances SEM (Brack-Hanes and Vaughn, 1978) and transmission electron microscopy (TEM; Taylor and Millay, 1977a, 1977b), only morphological details were obtained. The recent incorporation of more analytical techniques in various areas of paleobiology has resulted in an increased understanding of not only the biological nature of certain features, but also potential stages in the chemical alteration of fossil structures. To address these issues we have utilized Raman spectroscopy, a non-destructive vibrational technique, in order to provide increased information about the chemical composition of these inclusions.

Raman spectra were acquired from each taxon using a Renishaw inVia Reflex Raman microprobe. A $325 \mathrm{~nm}$ wavelength line of an aircooled Kimmon HeCd $20 \mathrm{~mW}$ laser was used to excite the samples, with a beam measuring $1 \mu \mathrm{m}$ in diameter. UV excitation was used rather than green excitation at 514.5 or $532 \mathrm{~nm}$, which is typically used for carbonaceous materials, in order to mitigate autofluorescence emission from such thermally immature organic matter. The Raman scattered light was dispersed with a $3600 \mathrm{~mm}$ /line diffraction grating, and the signal was analyzed with a Peltier cooled charge-coupled device (CCD) camera at room temperature $(1024 \times 256$ pixels $)$. A Leica DMLM microscope is coupled to the system, and two UV objectives $(\mathrm{LMU} \times 15 / \mathrm{NUV} 0.32$ and $\mathrm{LMU} \times 40 / \mathrm{NUV} 0.50)$ were used to view and analyze the samples. A diamond sample was used to calibrate Raman shift at one accumulation for $10 \mathrm{~s}$ using the $F_{2 g}$ mode at $1332 \mathrm{~cm}^{-1}$. Spectra were acquired using $100 \%$ laser power for one accumulation at an exposure time of $30 \mathrm{~s}$. Spectra were collected from three areas of the spores and pollen grains (intracellular inclusion, cell lumen, and surrounding matrix) of three cells from each taxon. Raman spectra were normalized using Renishaw software, converted to SPC files using Batch File Converter, and analyzed using GRAMS/32 software to obtain $\mathrm{I}_{\mathrm{D}}$ and $\mathrm{I}_{\mathrm{G}}$ values, as well as carbonate band positions. Additionally, GRAMS/32 software was used for the removal of cosmic rays, and several spectra were baseline corrected using Renishaw WiRE 3.3 ${ }^{\text {TM }} 158$ software. Slides used for Raman spectroscopy include: CB 15003 P3 TS1, CB 2124 C2-1 TOP TS1, and CB 902 E1B SIDE TS1.

\section{Results}

\subsection{Morphological analysis}

Observations utilizing transmitted light microscopy suggest marked variation among the inclusions of each taxon. This variation may be attributed to differences in the organization and perhaps morphological structure of central cell contents. Some inclusions in $P$. reedae appear grainy and the potential individual units within are darker than the surrounding matrix. The cell contents of $F$. schopfii suggest a more complex structure, since multiple components can be distinguished. For example, many of these inclusions contain a smaller, darker body which ranges from spherical to slightly irregular in shape. Lasiostrobus polysacci inclusions are spherical to ovoid in shape. Their internal appearance is more constant in comparison to the other taxa, with little variation in opacity within each structure.

The overall shape of the inclusions is moderately variable within each taxon. The inclusions in $P$. reedae range from spherical to ovoid, with some appearing slightly fragmented. More irregularity is found in the inclusions of $F$. schopfii. Within the specimens these structures are similar to one another, relatively round with some angular edges, but they do not possess a uniform morphology. In contrast, the inclusions of $L$. polysacci are relatively uniform in shape throughout, ranging from spherical to ovoid. The variation in shape observed within each taxon may be attributed to several factors. Some spores are found in different developmental stages, as in F. schopfii, with both solitary spores and immature tetrads. Variation could also be an artifact of preservation, as a result of changes occurring during diagenesis, or otherwise due to varying localities and depositional environments. All specimens are permineralized with calcium carbonate, and there does not seem to be any appreciable difference that might be attributable to slightly different ages. It is assumed that, at the chemical level, the material of all specimens is preserved by the same mechanisms.

Although fossil color has generally been underutilized in the field of paleobotany, the color of palynomorphs is extremely useful in determining the thermal maturation and history of the fossils (Staplin, 1977; Batten, 1982). The thermal alteration index (TAI) is a qualitative, color-based tool used to determine the intensity of heat exposure during diagenesis (Batten, 1996). The taxa in this study are quite similar in terms of color properties, indicating that all experienced a similar thermal history. The lumen of the spores and pollen grains, and the surrounding matrices are all similar in color, and the spore walls are easily discernible. All of these areas of the palynomorphs are monochromatic in the yellow to yellow-orange spectrum, with a TAI of 2-3 (Batten, 1996). This corresponds to a paleotemperature of $30-65{ }^{\circ} \mathrm{C}$ indicating that these specimens are thermally immature to mature as defined by the TAI (Batten, 1996).

The inclusions in P. reedae were described initially as nuclei containing well-defined chromatin granules (Baxter, 1950). Transmitted light microscopy shows a grainy appearance in many of these structures. One spore in particular contains an inclusion with a filamentous structure shaped like a chromosome; however, upon further investigation 
through thin section images and focal stacking, we contend that this "filament" is actually produced by viewing individual units of material belonging to separate focal planes. The central inclusions found in F. schopfii have been previously interpreted as interphase nuclei containing nucleoli, as well as nuclei containing prophase chromosomes (Brack-Hanes and Vaughn, 1978). Although the small spheroidal structures interpreted as nucleoli were found regularly throughout the specimens, we were unable to resolve any structures resembling chromosomes through the use of transmitted light microscopy, even with focal stacking techniques. As a result it was impossible to determine the ratio of putative genetic material to the total volume of the central structures of these specimens.

\subsection{Raman spectroscopic analysis and structural elucidation}

Raman spectroscopy is used to elucidate the molecular structures present in both a qualitative and quantitative manner. The vibration modes in Raman spectra are assigned by using Mulliken symmetry notation, which is standard practice in molecular spectroscopy. The intense broad vibration mode at ca. $1600 \mathrm{~cm}^{-1}$ is assigned to the " $\mathrm{G}$ " band, which is attributed to doubly degenerate in-plane stretching of $\mathrm{C}-\mathrm{C}$ bonds corresponding to the $E_{2 \mathrm{~g} 2}$ (Mulliken symmetry notation) mode of graphite. The weak broad vibration mode at ca. $1355 \mathrm{~cm}^{-1}$ is assigned to the "D" band which is due to a totally symmetric stretching mode corresponding to the $A_{1 g}$ mode of carbon doubly bonded and singularly bonded carbon atoms in six-fold aromatic rings that becomes an allowed Raman active mode due to disorder (i.e., lattice discontinuities or structural defects) or decreasing crystallite size (Plate II,1). Additionally, spectra show vibration modes at $1085 \mathrm{~cm}^{-1}$ assigned to the C - $\mathrm{O}$ totally symmetric stretching mode of $A_{g}$ symmetry of the trigonal planar $\mathrm{CO}_{3}$ polyhedron, which is due to the mineral calcite, attributed to the fossils originating from calcium carbonate concretions (Plate II, 1). The line-shape, bandwidth, and band intensity of the carbon firstorder region reflect molecular structure. The spectra shown here are indicative of a macromolecular structure of disordered carbonaceous materials. Structurally, these carbonaceous materials consist of polyaromatic clusters that are graphite-like domains typically consisting of 3-4 randomly stacked graphene layers. Quantitative analyses are presented in terms of the $\mathrm{I}_{\mathrm{D}} / \mathrm{I}_{\mathrm{G}}$ ratio, a ratio of the intensity of the $\mathrm{D}$ and $\mathrm{G}$ bands, which facilitates the comparison of the degree of order/disorder of carbonaceous materials making up the fossils. The $\mathrm{I}_{\mathrm{D}} / \mathrm{I}_{\mathrm{G}}$ range for all specimens was 0.5118-0.8042:0.5171-0.8042 for $P$. reedae, 0.5118-0.6296 for F. schopfii, and 0.6132-0.7153 for $L$. polysacci (Plate II, 2). We do observe a range in $I_{D} / I_{G}$ values in all the specimens, but there is no significant difference among the values for the matrix, the cell lumen, or the central inclusions.

\section{Discussion}

Our results demonstrate that although the cell contents of the reproductive propagules of these three Pennsylvanian plant taxa may resemble nuclei and other nuclear material morphologically, data from Raman
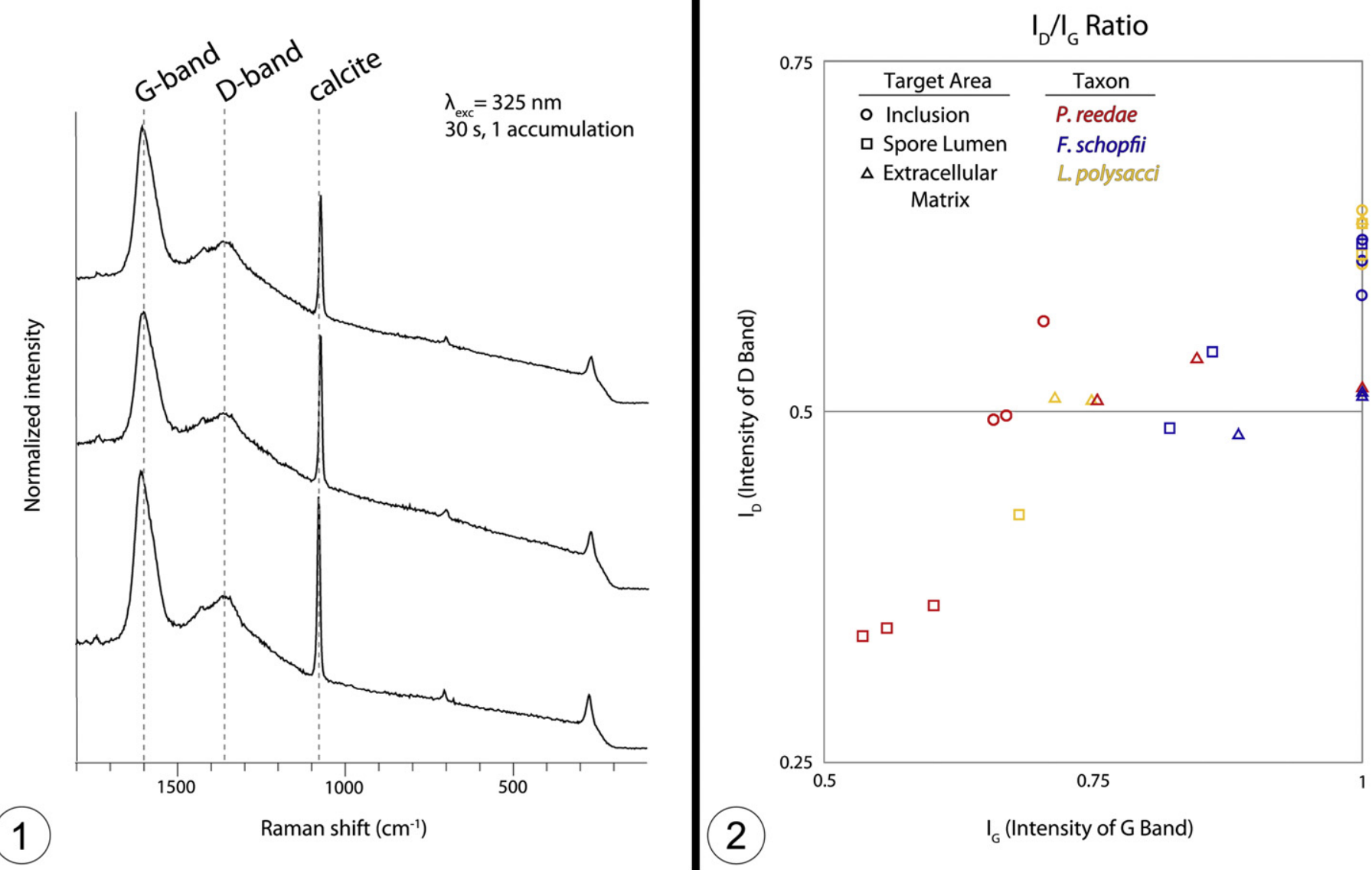

Plate II. 
spectroscopy do not confirm this idea. Raman spectra indicate that each of the inclusions in the three spore and pollen types is composed of disordered carbonaceous material in which the degree of order is the same. Although the morphology appears distinct, the chemical structure of the intracellular inclusions of each taxon does not differ significantly from that of the surrounding matrix or cell lumen. These results are perhaps not surprising due to the Paleozoic age and degree of diagenetic alteration of the specimens. It is unclear whether the disordered carbonaceous material is a product of the original plant material or has come from an external source. The latter hypothesis is less likely due to the complexity of such a process during permineralization. The molecular structure and composition of these samples do, however, clearly eliminate the possibilities of either proteinaceous material in its original state (i.e., chromatin) or mineral precipitation forming a type of template or mold around nuclei or chromosomes.

Several authors hypothesize that many central inclusions represent shrunken cell contents, resulting from changes that occurred prior to or during fossilization, including cytoplasm contraction and changes in cell size and morphology (Francis et al., 1978). A recent study used a combination of SEM with backscattered electron detection (BSE), TEM, and energy-dispersive X-ray spectroscopy (EDS) mapping to further investigate the inclusions of previously studied eukaryotic microfossils (Pang et al., 2013). These authors argue that observed intracellular inclusions are in fact protoplasts, either biologically or degradationally condensed, and not nuclei, due to the rapid degradation of nuclei following cell death, as well as the fact that, other more resistant organelles are not present in the exceptionally preserved cells (Pang et al., 2013). If the inclusions we have studied are not nuclei, similar chemical results could be expected from consolidated protoplast material within the cells.

Although many authors have suggested that the amplification of ancient DNA preserved in amber, bone, and other matrices is possible, modern contamination has been shown to be responsible for several of these claims (Willerslev and Cooper, 2005). Using mitochondrial DNA from radiocarbon-dated bones, the half-life of DNA has recently been estimated to be 521 years, meaning DNA may only be readable up to approximately $1.5 \mathrm{Ma}$ (Allentoft et al., 2012). These authors argue that it would be improbable to be able to amplify DNA found in much older material unless found in a "deep frozen" environment, in which case degradation occurs much more slowly. The depositional environment plays a major role in the time of degradation of these molecules, with temperature, $\mathrm{pH}$, and the presence of water all significant factors affecting breakdown.

There are still many accounts of other plant cell nuclei in the fossil record. For example, nuclei were described in parenchyma cells from the Magothy flora of Delaware, USA, thought to be fixated due to the acidic $\mathrm{pH}$ of surrounding water prior to or during fossilization (Penny, 1947). Spherical bodies were described from the embryonic cells of the silicified ovuliferous cone Araucaria mirabilis (Spegazzini) Windhausen, and suggested as possible protein granules, starch grains, or nuclei based on the presence of one per cell (Stockey, 1975). Recently, authors discovered exceptionally preserved cellular contents in the calcified stem of an osmundaceous fern (Bomfleur et al., 2014). Light microscopy, SEM, and SRXTM revealed consistently distributed nuclei containing discernible granules and chromosomes in various stages of cell division. Measurements also illustrated consistency in the size of nuclear material between extant and fossil materials, further supporting the proposed identity of these structures, although chemical analyses were not performed. Pinus-type pollen grains preserved in amber from the Baltic and Le Quesnoy, France containing intracellular "objects" were examined, and based on their size and general location were considered to be nuclei rather than preservational artifacts (Dejax et al., 2001). Such artifacts may include, for example, mineral precipitates within fossil cells. These studies have all relied on morphological data to identify intracellular structures. Although mineral precipitation has been the cause of much confusion in the interpretation of some fossil microstructures, modern analytical techniques such as Raman spectroscopy and EDS have proven useful in differentiating biogenic fossils from biomimetic mineral structures (Marshall et al., 2011; Klymiuk et al., 2013).

As paleobiology as a discipline moves forward, powerful analytical tools such as Raman spectroscopy are increasingly used to reexamine fossils in order to more accurately evaluate structural and taxonomic affinities. By adapting these modern techniques for the use in the fields of paleobiology and paleobotany, current studies may be augmented and future studies may become more reliable. We suggest the importance of the further examination of intracellular structures within the fossil record in order to irrefutably determine whether these represent preserved nuclei, or if other mechanisms produced these objects. Elemental data paired with structural and morphological data will complement studies of similar fossil structures of unknown affinities. It is our assertion that these tools will allow for a better understanding of structural morphology, the identification of elusive and problematic fossil contents and structures, and eventually the taphonomic mechanisms and processes that led to what we see in the fossil record today.

\section{Acknowledgments}

We wish to thank the University of Kansas (KU) Center for Undergraduate Research and the Howieson Opportunity Fund (KU Undergraduate Biology) for financial support through travel scholarships to ALG. We also thank the KU Department of Ecology and Evolutionary Biology, the KU Natural History Museum and Biodiversity Institute, and Dr. Rudolph Serbet for his help during the research process. The authors also thank two anonymous reviewers for their helpful comments and suggestions on an earlier draft. Research supported by the U.S. National Science Foundation (ANT-0943934 to ELT and TNT; EAR-1053241 to $\mathrm{CPM}$ and $\mathrm{AOM})$.

\section{References}

Aitken, J.F., Flint, S.S., 1995. The application of high-resolution stratigraphy to fluvial systems: a case study from the Upper Carboniferous Breathitt Group, eastern Kentucky, USA. Sedimentology 42, 3-30.

Allentoft, M.E., Collins, M., Harker, D., Haile, J., Oskam, C.L., Hale, M.L., Campos, P.F., Samaniego, J.A., Gilbert, M.T., Willerslev, E., Zhang, G., Scofield, R.P., Holdaway, R.N., Bunce, M., 2012. The half-life of DNA in bone: measuring decay kinetics in 158 dated fossils. Philos. Trans. R. Soc. B Biol. Sci. 279, 4724-4733.

Batten, D.J., 1982. Palynofacies, palaeoenvironments and petroleum. J. Micropalaeontol. 1, $107-114$

Batten, D.J., 1996. Palynofacies and petroleum potential. In: Jansonius, J., McGregor, D.C. (Eds.), Palynology: Principles and Applications, Volume 3-New Directions. Other Applications and Floral History. AASP Foundation, Dallas, pp. 1065-1084.

Baxter, R.W., 1950. Peltastrobus reedae: a new sphenopsid cone from the Pennsylvanian of Indiana. Bot. Gaz. 112, 174-182.

Bek, J., 2013. Microspinosporites, a new genus of Paleozoic pseudosaccate miospores of flemingitalean affinity. Bull. Geosci. 88.

Bomfleur, B., McLoughlin, S., Vajda, V., 2014. Fossilized nuclei and chromosomes reveal 180 million years of genomic stasis in royal ferns. Science 343, 1376-1377.

Bonde, S.D., Varghese, P., Kumaran, K.P.N., Shindikar, M.R., Gamre, P.G., 2004. Fossil chromosomes in an extinct Gondwanan seed plant (Pentoxylon). Curr. Sci. 87, 865-866.

Brack, S.D., 1970. On a new structurally preserved arborescent lycopsid fructification from the Lower Pennsylvanian of North America. Am. J. Bot. 317-330.

Brack-Hanes, S.D., Vaughn, J.C., 1978. Evidence of Paleozoic chromosomes from lycopod microgametophytes. Science 200, 1383-1385.

Courvoisier, J.M., Phillips, T.L., 1975. Correlation of spores from Pennsylvanian coal-ball fructifications with dispersed spores. Micropaleontology 21, 45-59.

Dejax, J., De Franceschi, D., Lugardon, B., De Ploëg, G., Arnold, V., 2001. Le contenu cellulaire du pollen fossilisé dans l'ambre, préservé à l'état organique. C. R. Acad. Sci. IIA Earth Planet. Sci. 332, 339-344.

Eggert, D.L., 1982. A fluvial channel contemporaneous with deposition of the Springfield Coal Member (V) Petersburg Formation, northern Warrick County, Indiana. Dept. Nat. Res. Indiana Geol. Surv. Spec. Rep. 28, 1-20.

Francis, S., Margulis, L., Barghoorn, E.S., 1978. On the experimental silicification of microorganisms. II. On the time of appearance of eukaryotic organisms in the fossil record. Precambrian Res. 6, 65-100.

Friis, E.M., Crane, P.R., Pedersen, K.R., Bengtson, S., Donoghue, P.C., Grimm, G.W., Stampanoni, M., 2007. Phase-contrast X-ray microtomography links Cretaceous seeds with Gnetales and Bennettitales. Nature 450, 549-552.

Galtier, J., Phillips, T.L., 1999. The acetate peel technique. In: Jones, T.P., Rowe, N.P. (Eds.), Fossil Plants and Spores: Modern Techniques. The Geological Society, London, pp. 67-70. 
Guennel, G.K., 1952. Fossil spores of the Alleghenian coals in Indiana. Indiana Geol. Surv. Rep. Prog. 4, 1-40.

Harvey, R.D., Dillon, J.W., 1985. Maceral distributions in Illinois coals and their paleoenvironmental implications. Int. J. Coal Geol. 5, 141-165.

Hass, H., Rowe, N.P., 1999. Thin sections and wafering. In: Jones, T.P., Rowe, N.P. (Eds.), Fossil Plants and Spores: Modern Techniques. The Geological Society, London, pp. 76-81.

Klymiuk, A.A., Harper, C.J., Moore, D.S., Taylor, E.L., Taylor, T.N., Krings, M., 2013. Reinvestigating Carboniferous "actinomycetes": authigenic formation of biomimetic carbonates provides insight into early diagenesis of permineralized plants. PALAIOS $28,80-92$.

Maples, C.G., 1986. Enhanced paleoecological and paleoenvironmental interpretations result from analysis of early diagenetic concretions in Pennsylvanian shales. PALAIOS $1,512-516$.

Marshall, C.P., Edwards, H.G.M., Jehlicka, J., 2010. Understanding the application of Raman spectroscopy to the detection of traces of life. Astrobiology 10, 229-243.

Marshall, C.P., Emry, J.R., Olcott Marshall, A., 2011. Haematite pseudomicrofossils present in the 3.5-billion-year-old Apex Chert. Nat. Geosci. 4, 240-243.

Nasdala, L., Beyssac, O., Schopf, J.W., Bleisteiner, B., 2012. Applications of Raman-based images in the earth sciences. In: Zoubir, A. (Ed.), Raman Imaging Techniques and Applications. Springer, Berlin Heidelberg, pp. 145-187.

Olcott Marshall, A., Wehrbein, R.L., Lieberman, B.S., Marshall, C.P., 2012. Raman spectroscopic investigations of Burgess Shale-type preservation: a new way forward. PALAIOS 27, 288-292.

Pang, K., Tang, Q., Schiffbauer, J.D., Yao, J., Yuan, X., Wan, B., Chen, L., Ou, Z., Xiao, S., 2013. The nature and origin of nucleus-like intracellular inclusions in Paleoproterozoic eukaryote microfossils. Geobiology 11, 499-510.

Penny, J.S., 1947. Studies on the conifers of the Magothy flora. Am. J. Bot. 34, 281-296.

Pflug, H.D., Jaeschke-Boyer, H., 1979. Combined structural and chemical analysis of 3800Myr-old microfossils. Nature 280, 483-486.

Schopf, J.W., 1968. Microflora of the Bitter Springs Formation, Late Precambrian, central Australia. J. Paleontol. 42, 651-688.

Schopf, J.W., Kudryavtsev, A.B., Agresti, D.G., Czaja, A.D., Wdowiak, T.J., 2005. Raman imagery: a new approach to assess the geochemical maturity and biogenicity of permineralized Precambrian fossils. Astrobiology 5, 333-371.
Schopf, J.W., Ttipathi, A.B., Kudryavtsev, A.B., 2006. Three-dimensional confocal optical imagery of Precambrian microscopic organisms. Astrobiology 6, 1-16.

Staplin, F.L., 1977. Interpretation of thermal history from color of particulate organic matter: a review. Palynology 1, 9-18.

Stockey, R.A., 1975. Seeds and embryos of Araucaria mirabilis. Am. J. Bot. 62, 856-868.

Tarcea, N., Harz, M., Rosch, P., Frosch, T., Schmitt, M., Thiele, H., Hochleitner, R., Popp, J., 2007. UV Raman spectroscopy - a technique for biological and mineralogical in situ planetary studies. Spectrochim. Acta A Mol. Biomol. Spectrosc. 68, 1029-1035.

Taylor, T.N., 1970. Lasiostrobus gen. n., a staminate strobilus of gymnospermous affinity from the Pennsylvanian of North America. Am. J. Bot. 670-690.

Taylor, T.N., Millay, M.A., 1977a. Structurally preserved fossil cell contents. Trans. Am. Microsc. Soc. 96, 390-393.

Taylor, T.N., Millay, M.A., 1977b. The ultrastructure and reproductive significance of Lasiostrobus microspores. Rev. Palaeobot. Palynol. 23, 129-137.

Taylor, W.A., Free, C., Boyce, C., Helgemo, R., Ochoada, J., 2004. SEM analysis of Spongiophyton interpreted as a fossil lichen. Int. J. Plant Sci. 165, 875-881.

Taylor, T.N., Krings, M., Dotzler, N., Galtier, J., 2011. The advantage of thin section preparations over acetate peels in the study of late Paleozoic fungi and other microorganisms. PALAIOS 26, 239-244.

Treworgy, C.G., Jacobson, R.J., 1986. Paleoenvironments and distribution of low-sulfur coal in Illinois. Ninth International Congress on Carboniferous Stratigraphy and Geology 4 Illinois Department of Energy and Natural Resources, State Geological Survey Division, pp. 349-359.

Wanless, H.R., Baroffio, J.R., Trescott, P.C., 1969. Conditions of deposition of Pennsylvanian coal beds. Geol. Soc. Am. Spec. Pap. 114, 105-142.

Willard, D.A., DiMichele, W.A., Eggert, D.L., Hower, J.C., Rexroad, C.B., Scott, A.C., 1995 Paleoecology of the Springfield Coal Member (Desmoinesian, Illinois Basin) near the Leslie Cemetery paleochannel, southwestern Indiana. Int. J. Coal Geol. 27, 59-98.

Willard, D.A., Phillips, T.L., Lesnikowska, A.D., DiMichele, W.A., 2007. Paleoecology of the Late Pennsylvanian-age Calhoun coal bed and implications for long-term dynamics of wetland ecosystems. Int. J. Coal Geol. 69, 21-54.

Willerslev, E., Cooper, A., 2005. Ancient DNA. Philos. Trans. R. Soc. B Boil. Sci. 272, 3-16

Williamson, W.C., 1893. On the organization of the fossil plants of the coal-measures. Part XIX. Philos. Trans. R. Soc. B 184, 1-38. 